\title{
The Socio-economic Impact of Climate Change on Marine and Freshwater Fisheries Resources in the Coastal Zone of the Gambia
}

\author{
Joshua Amuzu \\ West African Science Service Center on Climate Change and Adapted Land Use (WASCAL) Headquarters, CSIR Office Complex, \\ Airport Residential Area, P.M.B CT 504, Cantonments-Accra, Ghana
}

Copyright $(2018$ by authors, all rights reserved. Authors agree this article remains permanently open access under the terms of the Creative Commons Attribution License 4.0 International License

\begin{abstract}
The fisheries sector is a vital source of overseas exchange and income for the financial and social advancement needs in most part of the world. However, challenges like the low level of research and education on the prospects of this sector to front-runners, business-oriented financiers across the Sub-region has contributed to low investment and development of this sector. Giving the prospects this sector presents, Climate Change (CC) impacts may compromise the Coastal Zone's (CZ) ability to deliver benefits derived from fisheries resources. This study seeks to characterize the trend of artisanal and industrial fisheries catches in The Gambia from 1986-2016 with projected trends to the year 2025. The study will further estimate the effects of climate change on the productivity of fisheries resources in River Gambia and; estimate the effects of climate change on shrimp yield on the sheltered coast of The Gambia to the year 2100 . The results of the study reveal industrial fishery catches is decreasing at 534 MT annually over the period 1968- 2014. This observed negative trend is predicted to decrease from 4,770 MT in 2014 to 66.7 MT by the year 2025. The artisanal fisheries sector, contrariwise, revealed a positive trend of 1,611 MT per annum from 1986-2016. It is predicted this trend will increase from 58,261.6 MT in 2016 to 70,651.8 MT by the year 2025; this relates to an increase of approximately 21\%. By the year 2100, there will be a potential increase of sustainable shrimp yield in The Gambia by $46 \%$, while the productivity of the River Gambia in support of fisheries resources will increase by $13 \%$. This result reveals that by the end of this century, The Gambia maritime space, and its river framework, will continue to be productive in the support of shrimp and other artisanal fisheries resources under the anticipated impacts of CC on the CZ.
\end{abstract}

Keywords Socio-economic Impact, Climate Change, Shrimp, Coastal Zone, Artisanal Fisheries, Industrial
Fisheries, Trend Analysis, River Gambia, The Gambia

\section{Introduction}

The fisheries sector is a vital source of overseas exchange and income for the financial and social advancement needs in most part of the world. As at 2015, the world marine fisheries capture was 81,164,685 tonnes with a net increase of $1.7 \%$ from the previous year [1]. The value added by the fisheries subdivision in 2011 was evaluated at more than US \$24 billion, corresponding to $1.26 \%$ of the Gross Domestic Product (GDP) of every single African nation [2]. The total value added from fishing and aquaculture alone in Africa is over US \$17.4 billion [2]. The West African Sub-region has over 6,069 $\mathrm{km}$ of Coastal Zone (CZ) and an Exclusive Economic Zone (EEZ) of 2,016,900 $\mathrm{km}^{2}$ that support fishing and other economic activities [3]. Although the leading producers of fisheries resources in this region are; Mauritania, Ghana, Senegal, and Nigeria [2], The Gambia is ranked as the sixth most productive fishing area in the world [4]. This raises prospects for fishing in the marine and estuary ranges of the River Gambia.

The Fisheries sector has turned into a market-driven, dynamically emerging area for food security due to the increasing interest and demand for fish and its products [5, 6]. Many coastal states in Africa are endeavouring to grab the new opportunities this sector presents by putting resources into contemporary angling vessels and fish processing plants $[5,7]$. The Gambian economy has, until as of late, been vigorously subject of rain-fedagriculture. However, following the severe drought of the mid-1970's and 1980's leading to food security threats from a decline in productivity levels recorded in agriculture and animal husbandry, the Government of The Gambia resolved to 
seek recompense from other economic sectors [5, 7]. Against the background of low profitability, rain-sustained agribusiness and the nation's bestowed with a copious and various supplies of fish resources like: cephalopods, crustaceans, pelagic fish and shrimp in its river and marine waters, the focus is gradually shifting to the fisheries sector. This sector represents a segment with extraordinary potential to significantly commit to the social and financial advancement needs of The Gambia [5]. This sector is also thought to have prospects in contributing to accomplishing the nation's more noteworthy food security policy objective and to the improvement of its monetary base at large [5, 7]. Over the year 2013 for instance, the total contributions of fisheries to GDP of The Gambia was 5.7\% [1]. A likely 200,000 individuals in The Gambia are specifically or secondarily associated with fisheries and its related activities with dependence on the division for their financial needs with its resources turning into the most imperative wellspring of animal protein for both rustic and urban dwellers [8]. The contributions of artisans, industrial and shrimp fisheries are discussed in turns in the forthcoming paragraphs.

In recent decades, artisanal fisheries in West Africa have extended enormously with the provision of over $27 \%$ of animal food protein and income streams [9]. This division is also a notable wellspring of primary and secondary occupations for people at the national to local level. The total employment from fisheries in Africa is estimated to be over 1.9 million people with total Inland fisheries accounting for $40.4 \%$, whiles total marine artisanal fisheries contributing $32.9 \%$ [2]. The artisanal fishers in this study allude to fisherfolk with low capital, and fish utilizing little gear and innovation like canoes, hook and line, among many others. With The Gambia, artisanal fishers likewise incorporate the women oyster collectors and shrimp farmers who largely work inside the estuarine ranges. Regardless of the operations of artisanal fisheries in The Gambia, they contribute over $90 \%$ of the aggregate national fish utilization in the country [1]. They supply around $80 \%$ of throughput in the modern fisheries management plants of The Gambia [1].

The marine, industrial fisheries sub-sector in Africa alone contributes to a net worth of over US \$3 billion from an estimated annual catch of 1.6 million tons [2]. Most African countries benefit from fishing agreements of the European Union (EU) regarding industrial fishing in territorial waters [10]. For instance, the EU pays Mauritania 86 million euros annually, which relates to approximately a third of Mauritania's national income [11]. The marine industrial fisheries sector alone accounts for over $0.36 \%$ of the total employment in Africa [2]. The industrial fishing in The Gambia, for instance, represents as meagre as $10 \%$ of the aggregate national fish utilization, and about $20 \%$ of the locally-processed fisheries [12]. The industrial fishing sector in this study encompasses the use of high-cost fish production frameworks with fishing trawlers chiefly focused along the Atlantic coast. Due to the relatively high cost of machinery and initial capital investment involved in industrial fishing activities, most indigenes along the coastal zones of many West African countries engage in more artisanal fishing than industrial fishing operations $[10,13,14]$. Other fisheries products harvested within the marine and the River Gambia estuary ranges are shrimps. The industrial fisheries sector has exploited more of this fishery resource, in contrast with artisanal fisheries sub-sector due to constraints in capital, technology, research and development, low level of awareness on the prospects this sector presents, among many other reasons [15].

Shrimps are the world's most expended fisheries products with around $16 \%$ of worldwide exchange in monetary value terms [16]. In 1976, shrimp production, adding up to 1.5 million tons ascended by over 1 million tons from 5.6 million tons in 2003 to 6 million tons in 2004 [17]. In 2004, total cultivated shrimp from Africa was about 8,000 tons, which corresponds to less than $1 \%$ of the aggregate world supply of aquaculture production [16]. From that point forward, it is sure that the extent of worldwide supplies has diminished mainly because of the stagnation of African shrimp production whiles areas like Asia continued to be the main suppliers of this fisheries product to the world market $[16,17]$. This creates a market gap to be filled.

The ecological sustainability in the West Africa Sub-Region has become a premise necessitating the improvement of shrimp cultivating in this region [16, 18]. From an essential topographical perspective, numerous tributaries in most West Africa nations from Senegal to Nigeria make them ecologically apt for shrimp cultivating [16]. Broad territories of level land behind mangrove zones exist in addition to open waterfront planes where shrimp ponds can be developed in these countries. The demand for shrimp is expanding and wild shrimp fisheries in West Africa are declining bit-by-bit [16, 18]. This notwithstanding, there is as of now just a single delivering ranch in West Africa, "West Africa Aquaculture", in an estuary in The Gambia River [16]. With an annual production of around 50 tons of substantial Penaeus monodon species of shrimps, this production is as of now the main working homestead in the Sub-region [16]. Challenges like: low level of research and education on the prospects of this sector to front-runners, business-oriented financiers across the Sub-region has contributed to low investment and development of this fisheries sub-sector. This has led to more industrial than artisanal shrimp fisheries operations. In the year 2007 for instance, 32 modern fishing vessels worked with a permit in Gambian marine waters; 15 were shrimp trawlers while 17 were fish or cephalopod trawlers [19]. The Gambia's fundamental trading associates as far as fish and fisheries items are concerned are the EU with over $70 \%$ of the aggregate volume of export-bound for EU markets [5]. Giving all these prospects of fisheries to economies and individuals in countries, Climate Change (CC) impacts may compromise 
the coastal zones ability to deliver these prospects.

The IPCC AR5 [20] predicts with high confidence that climate change will cause an increase in acidification and a surge in ocean temperatures. This incident will lead to potential effects on fisheries numbers and distribution. Another issue of concern is that marine biological systems, including coral reefs and the fisheries that rely upon them, are anticipated to be amid the regular frameworks influenced by climate change in the shortest time [6, 21, 22]. The ascent and changes in variables like: sea surface temperature, salinity, wind speed, quality of upwelling, and predator relations to climate change can alter fish-reproducing natural environs and eventually the number of the fish populace in the waters $[6,18,23]$. Under increased salinity conditions of the oceans, the survival of some marine resources will likewise be at-risk [6, 20, 24].

At large, fisheries resources are transboundary with no precincts at the regional to the local level in maritime space. This makes it easy for them to relocate to areas that are more favourable for their survival and reproduction; thus contributing to variations in fisheries stock over varied locations. Managing adequate access to fish under pressings climatic stresses will entail the reception of actions intended to ensure the preservation of specific fish species in danger of extinction in particular regions, while increasing the exploitation of others that are in abundance $[6,25]$. This can be revealed by characterizing the trend of fisheries production in artisanal and industrial subsectors and an in-depth analysis of the productivity of freshwater resources in support of other fisheries production like shrimps under varying climatic impacts.

The impacts of climate change correspondingly have social and security ramifications. For instance, in The Gambia, technological advancements and some fish stock shortage have induced more artisanal fishers to go over 200 nautical miles seaward in the areas allocated to foreign vessels [12]. This incidence leads to several confrontations between foreign and local fishers raising safety concerns at sea. Although it is not conceivable to sum up the effects of changes in environmental factors on fisheries in Sub-Sahara Africa (SSA), they share something in like manner - climate change will likely prompt variances in fisheries stocks [18, 22]. Changes in fisheries stocks will have major financial effects on nations that rigorously rely on this sector for their GDP like the case of The Gambia. This leads to the motivation of this study. This study will seek to: characterize the trend of artisanal and industrial fishery catches in The Gambia from 1986- 2016 and give informed predictions on the trend of these resources until the year 2025. The study will further estimate the effects of temperature on the productivity of fisheries resources in River Gambia and; estimate the Effects of Temperature Changes on Shrimp Yield in the sheltered coast of The Gambia on a decadal basis up to the year 2100 .

There have been different school of thought on the under or over-utilization of fisheries resources in The Gambia maritime space and the freshwater resources of the River Gambia framework. The realization of these objectives will aid in revealing the potentials of the fishery catches and give a sense of direction on what the situations will be in the short-medium term for a more sustained use of these resources. The estimations of the sustainable shrimp yield under projected General Circulation Models (GCMs) temperature predictions up to the end of this century is pertinent in helping individuals and key stakeholders in making a more informed choice in investment in this sub-sector. This will aid in luring more foreign direct investment to boost this fisheries segment; this brings social and economic gains to The Gambian economy. Additionally, this will allow entrepreneurs; fisherfolk and; individuals obtain more income diversification opportunities to increase their resilience to climate change and its variability. The study will assist front-runners in the Government institutions, Non-Governmental Agencies (NGOs) and researchers in the unremitting development of strategies to sustain the sector, and eventually, render it competitive in niche markets and the incorporation of shrimp farming within coastal zone management plans of The Gambia.

\section{Materials and Methods}

\subsection{Characterizing the Trend of Industrial and Artisanal Fishery Catches in the Gambia}

To characterize the trend of artisanal and industrial fishery catches in The Gambia from 1986- 2016, a line graph is drawn to show the trend of Fisheries (in MT) in the study area (Figure 1). The time-series data used in this analysis is sourced from the Department of Fisheries. The growth rate over the period is estimated using the simple linear regression model below (1);

$$
\mathrm{Y}_{\mathrm{t}}=\beta_{0}+\beta_{\mathrm{i}} \mathrm{T}+\mathrm{e}_{\mathrm{i}}
$$

where: $Y_{t}=$ Artisanal or Industrial Fisheries (in MT); $\beta_{0}=$ Intercept, $\beta_{\mathrm{i}}=$ Growth rate $/$ Trend; T = Time (1985- 2016); $e_{i}=$ Error.

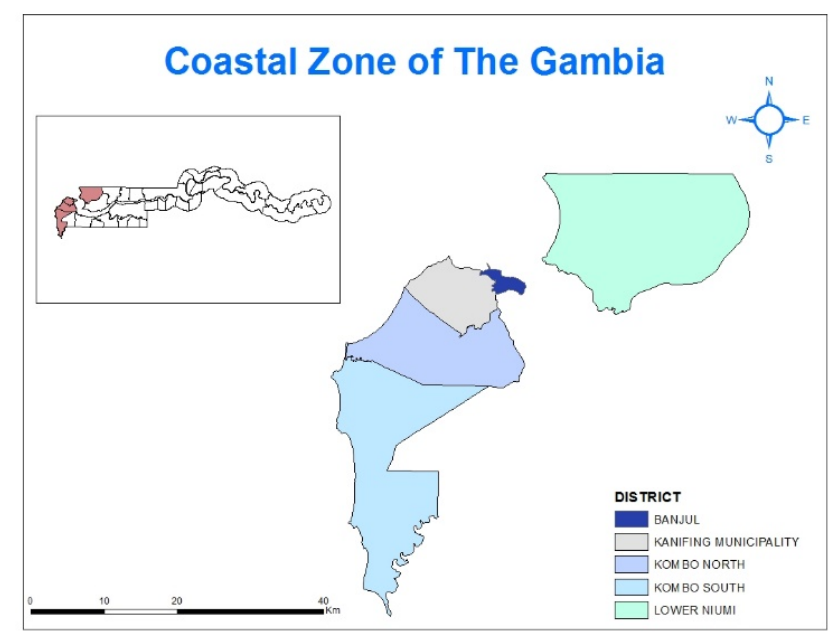

Figure 1. Map of the Study Area, the Coastal Zone of the Gambia 


\subsection{Estimating the Effects of Temperature on the Productivity of the River Gambia Fisheries Resources}

The model developed by Welcomme [26] is used in estimating the annual productivity of the River Gambia based on its average stream width, biogenic capacity, average annual temperature, acidity or alkalinity and the fish population present in the river. The area covered ranges from the mouth of the river to Bamba Tenda/ Yelli Tenda crossing point of The Gambia. This can be estimated using (2).

$$
\mathrm{K}=\mathrm{B} \times \mathrm{L} \times\left(\mathrm{K}_{1} \times \mathrm{K}_{2} \times \mathrm{K}_{3}\right)
$$

Where: $\mathrm{K}=$ Annual Productivity $(\mathrm{kg} / \mathrm{km}) ; \mathrm{L}=$ Average width of the river $(\mathrm{m})$; $\mathrm{B}=$ Biogenic Capacity; $\mathrm{K}_{1}=$ average annual temperature; $K_{2}=p H$ of the River; $K_{3}=$ the fish population present.

The value of the Active width of the River Gambia, L is estimated from the 2016 bathymetric map of The Gambia, sourced from the Gambia Ports Authority, L=4,900m. The Biogenic Capacity, $\mathrm{B}$ is given by: $\mathrm{B}=1-3$ for waters with little fish food; $B=4-6$ for waters with average fish food and; $B=7-10$ for waters rich in fish food. For the case of The Gambia, its river has an average fish food [27], the value of $\mathrm{B}=6$ for the study. The average $\mathrm{pH}$ of the River Gambia from the mouth of the river to the Bamba Tenda/ Yelli Tenda crossing point, $\mathrm{K}_{2}=7.16$. This is obtained from field measurements validated by the Hydrology Unit of the Department of Water Resources of The Gambia, Banjul. The value for the fish population present, $K_{3}$ is estimated based on the percentage of rheophic (fast flowing water) and limnophilic (slow flowing water) species in the fish community of the river. The value of the fish population present, $K_{3}$ is given as (3).

$$
\mathrm{K}_{3}=(2 \mathrm{~L}+\mathrm{R}) / 100
$$

where: $\mathrm{L}=$ percentage of the fish community comprising limnophilic species, $\mathrm{R}$ = percentage of the fish community comprising rheophilic species.

The values of $\mathrm{L}$ and $\mathrm{R}$ in the study are taken as $95 \%$ and $5 \%$ respectively for the River Gambia as most part of the river is flowing with more community of limnophilic species [28]. The GCMs used are the Canadian Climate Center Model (CCCM199), Geophysical Fluid Dynamics Laboratory (GFDL90) and the Australian model (BMRC95). These three GCMs have the highest correlation coefficients ( $r$ ) with the baseline climatic data extracted from the SCENGEN climate model used in this study. The data for 1981- 2010 is the baseline climate scenario for the study. This secondary data is sourced from The Gambia's first national communications report to the United Nations Framework Convention on Climate Change [12] and is given as Appendix (A).

\subsection{Estimating the Effects of Temperature Changes on Shrimp Yield}

To assess the effects of different temperature scenarios on the yield of shrimps in the sheltered coast of The Gambia, Regier et al [29] model is adopted. This method has been adopted in varied studies [29-31]. The correlation coefficients (r) used for the model is $58 \%$. This is given as (4);

$$
\log _{\mathrm{e}} \mathrm{SCSY}_{\mathrm{i}}=52.0-14312\left(1 / \mathrm{T}_{\mathrm{i}}\right)
$$

where: SCSY $=$ Stabilized Commercial Shrimp Yield ( $\mathrm{kg} / \mathrm{ha}$ of intertidal vegetation); $\mathrm{T}=$ Mean annual Temperature $\left({ }^{\circ} \mathrm{K}\right)$.

\section{Results and Discussion}

\subsection{Trend of Annual Industrial and Artisanal Fishery Catches}

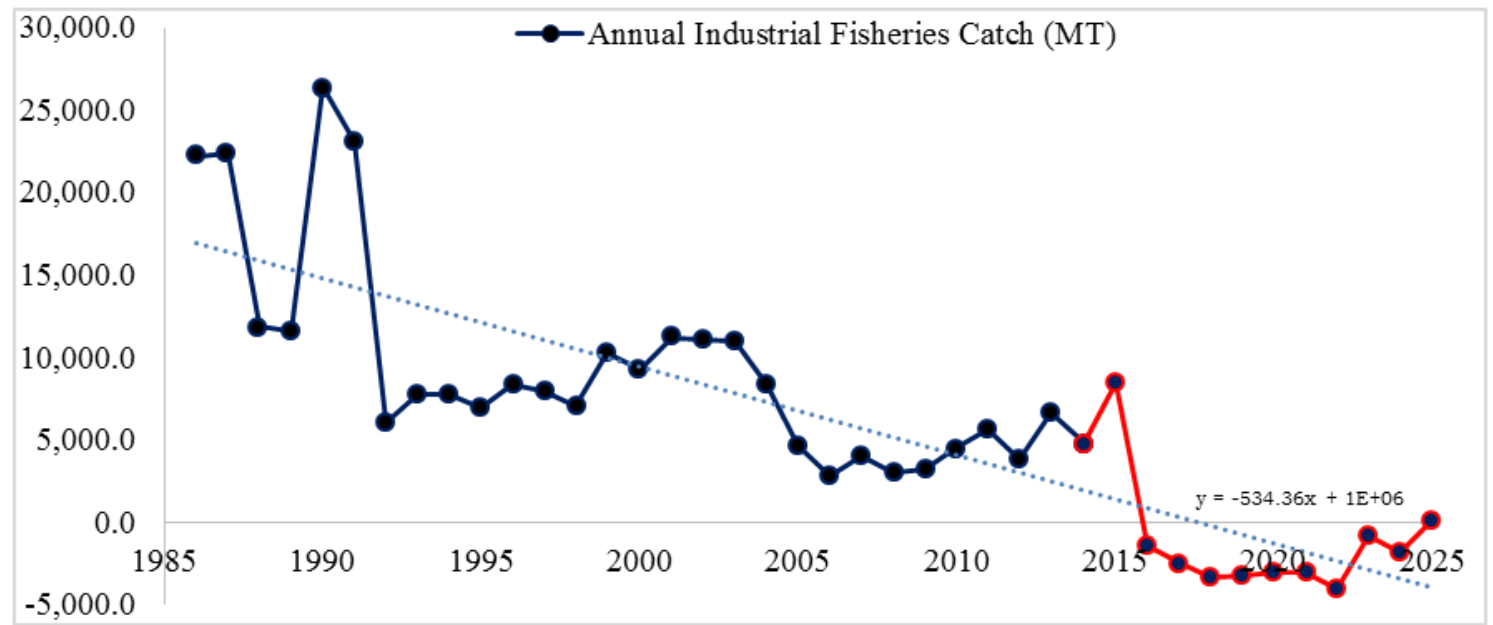

Figure 2. The trend of Annual Industrial Fishery Catches (in MT) from 1986- 2014 (number of years) and Forecast values from 2015 -2025 
Figure 2 shows the trend of annual industrial fishery catches from 1986-2014 and its forecast values from 2015-2025 over the coastal zone of The Gambia. From the graph (Figure 2), annual industrial fishery catches over the past three decades shows a decreasing trend at an approximate rate of 534 MT per annum in The Gambia (Table 1).

This observed trend deviates from the positive values observed in the industrial fisheries capture in Kenya, Madagascar, Mozambique, Seychelles, South Africa and Tanzania over the years $1985-2012$ [18, 19, 32-40]. Angola and other Southern African countries recorded a positive trend in industrial fishery catch from 1960-1990 [41]. A positive trend was observed in industrial fishery catches in the Southern Coast of Brazil from 1998-2001 [42]. This may be due to the restriction placed on deep-sea fishing by the Brazilian Government until 1998 where the ban was lifted. This time lapse allowed for the natural regeneration of fisheries resources, as there was less interference in the fisheries ecosystem. This measure supports sustainable fisheries.

Table 1. Estimated Growth Model of Annual Industrial Fishery Catches from 1986- 2014

\begin{tabular}{|c|c|lr|}
\hline Variable & Coefficient & \multicolumn{2}{|c|}{ Standard Error } \\
\hline Trend (T) & -534.36 & \multicolumn{2}{|c|}{101.02} \\
\hline Intercept (C) & $1,078,142.76$ & \multicolumn{2}{|c|}{202034.46} \\
\hline R- Square & 0.51 & F-statistics & 27.98 \\
\hline Adjusted R-Square & 0.49 & Prob(F-statistics) & 0.0001 \\
\hline
\end{tabular}

Among the factors that may have contributed to the observed negative trend in The Gambia are; although the Government has given motivators like duty-free exports and import duty exclusions on fishing-related gears, most part of the advances in this sector is left for the private sector inventiveness [12, 43]. The benefit of duty-free fuel in the fisheries sector was put on hold in 1994, during which period recorded a significant increase in the industrial fisheries capture in The Gambia [43]. The rigorous process vessel owners must go through to obtain and renew their fishing licenses may have contributed to the observed trend in the study. And some industrial fishing vessels are engaged in practices like under-declaration of fisheries resources caught at various fish-landing sites [12, 13, 18, 24, 32, 44, 45]. Illegal and unreported fishing contribute to overexploitation of fisheries stock. It is a hindrance to the recovery of fish populations and ecosystems [45]. This is partly given the fact that catches of industrial vessels are exported directly from the fishing grounds for landing outside The Gambia. The point that The Gambia does not have a deep-water port committed to modern industrial fishing operations is utilized to legitimize the landing and handling of fish exploited in its territorial waters by the overseas vessels in nations outside The Gambia [5, 12, 43]. These fisheries landings are not reflected as exports and hence may likely reflect the observed trend of the study [5]. In anticipation of sustainable fishing, the government of The Gambia placed a ban on beach seine net and importation and use of monofilament nets, which are non-biodegradable; this may have contributed to the reduction of the number of industrial fishing activities that do not conform to these directives [44]. Although annual industrial fishery catches experienced a decreasing trend, over the last decade, there has been observed increases in some years like; 2001, 2007, 2009, 2010, 2011, and 2013. In some years, tax incentives were increased besides the facilitation of the process of acquisition and renewing of fishing licenses [44]. The Government of The Gambia placed a ban on industrial fishing activities over the years 2015 and 2016, this accounts for the lapse in the data on these years.

With 95\% confidence interval and a Mean Absolute Percent Error (MAPE) of 3\%, the study predicts that the observed decline in the fisheries resources from industrial fishing will persist to the year 2022 and then there will be a steady increase to the year 2025 . There may be a decrease from 4,770 MT in 2014 to 66.7 MT by the year 2025 if urgent actions are not engaged to reverse this predicted trend.

Figure 3 shows the trend of annual artisanal fishery catches from 1986-2016 and its forecast values from 2017-2025 over the study area. From the graph (Figure 3), annual artisanal fishery catches over the past three decades has been increasing at an approximate rate of 1,611 MT per annum in the study area (Table 2). The positive trend in annual artisanal fishery catches is supported by studies in Ghana, Nigeria, Senegal, Cameroon and Brazil [10, 39, 40, 46-49]. A negative trend was observed in the artisanal fishery catches in the Southern Coast of Brazil from 19982001 [42]. This is largely due to the ban placed by the Government on deep-sea fishing along the southern coastline of Brazil before 1998. This led to increased exploitation of fisheries resources by local and industrial vessels within the areas allocated for artisanal fishing.

The positive trend in artisanal fisheries suggests that the fisheries resources in The Gambia are likely under-utilized [43]. The renovation of the artisanal fishery from paddling canoes with simpler but less efficient fishing methods to one with present day fish catching machinery and bigger canoes with outboard motors likely contributed to the positive trend observed in this sector. An increase in population growth rate, higher demands for jobs, especially among the youth, and relocation into the fisheries sector as the agriculture segment kept on declining under increased climatic stress has driven the development of this fisheries sector [43]. Although annual artisanal fishery catches experienced an increasing trend, over the last decade, there has been observed decreases in some years like; 2008, 2010, 2012, and 2013. With 95\% confidence interval and a MAPE of 6\%, it is predicted that the observed increase in artisanal fishery catches will persist to the year 2025. The 2016 value of 58,261.6 MT is predicted to increase to $70,651.8$ MT by 2025. By the year 2020, the study predicts that the artisanal fishery catches will increase by $14 \%$ (66,563.2 MT) parallel to the 58,261.6 MT in 2016. 


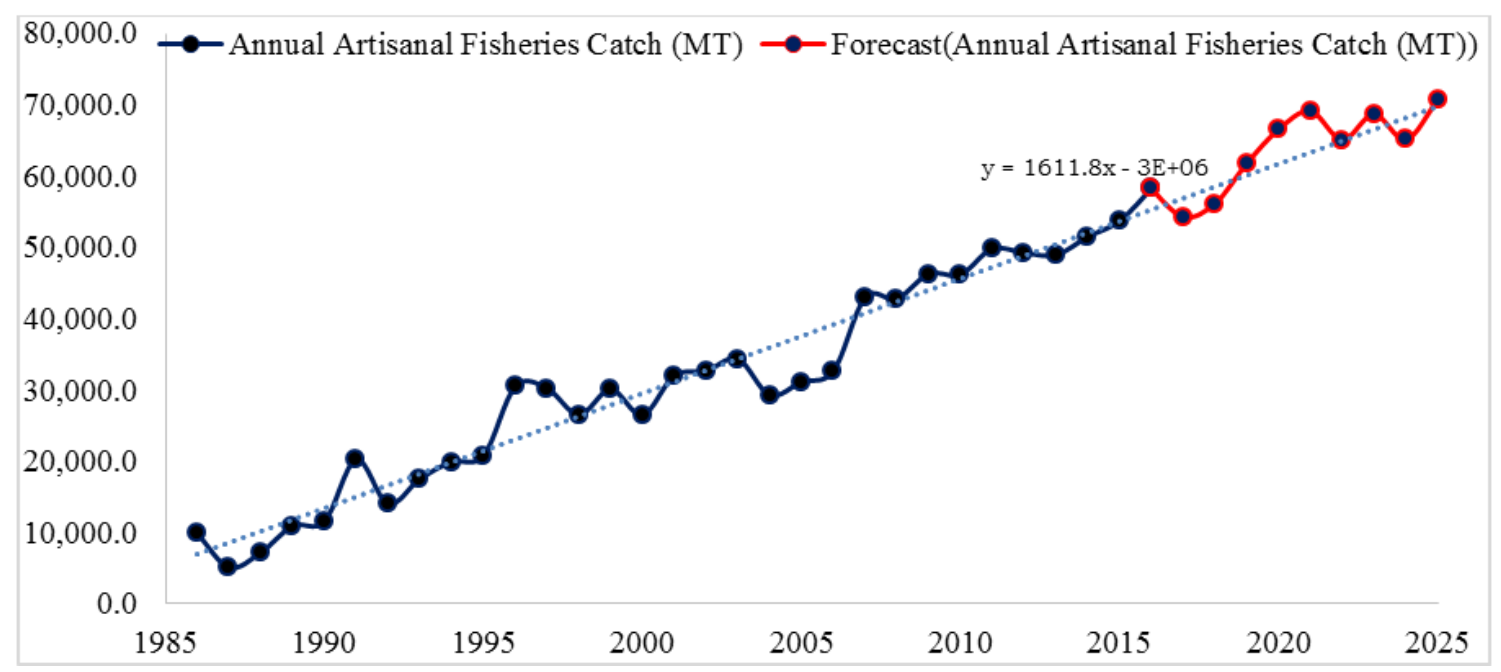

Figure 3. The trend of Annual Artisanal fishery catches (MT) from 1986- 2016 (number of years) and Forecast values from 2017-2025

Table 2. Estimated Growth Model of Annual Artisanal Fisheries Catches from 1986-2016

\begin{tabular}{|c|c|cc|}
\hline Variable & Coefficient & \multicolumn{2}{|c|}{ Standard Error } \\
\hline Trend (T) & $1,611.82$ & \multicolumn{2}{|c|}{67.39} \\
\hline Intercept (C) & $-3,194,187.11$ & \multicolumn{2}{|c|}{$134,851.79$} \\
\hline R- Square & 0.95 & F-statistics & 572.04 \\
\hline Adjusted R-Square & 0.94 & Prob(F-statistics) & 0.0000 \\
\hline
\end{tabular}

\subsection{Assessing the Effects of Temperature on Productivity of Riverine Fisheries Resources}

Figure 4 shows the annual productivity of the River Gambia in support of riverine fisheries under varied mean annual water temperatures. The baseline productivity of the River Gambia based on a temperature of $28.0^{\circ} \mathrm{C}$ (from years $1981-2010$ ) is $11,493.5 \mathrm{MT} / \mathrm{km}$.

In synopsis, the results of the analysis revealed an anticipated increase in the productivity of riverine fisheries resources by $9 \%$ by 2060 and a steady increase of $13 \%$ by the year 2100 under the varied GCM scenarios. Randall et al [50] study supports the result of this study, showing a positive trend in the productivity of rivers in support of fisheries resources in contrast with lakes. Acreman [51] study supports this result showing a positive trend in the productivity of the Senegal River in support of fisheries resources. Predictions by Houde and Rutherford [52] reveal a positive trend in the productivity of rivers regarding fisheries resources, supporting the result. The Murray-Darling river system in Australia showed a positive trend in the productivity of the river in support of fisheries in Australia under varied temperature [53]. However, the main factor that could dip the productivity of the Australian river was found to be unregulated fishing practices. This could lead to the introduction of alien species that can reduce the numbers of other species in the food chain within the riparian ecosystems.

In elucidation, by the year 2020, it is predicted that the productivity of the river in support of fisheries resources will increase by a maximum value of 3\% (CCCM199) with at least 2\% increase (BMRC98 and GFDL90). By the year 2030, it is predicted that productivity will increase by a maximum value of 4\% (CCCM199 and BMRC98) with a minimum increase of 3\% (GFDL90). Through the year 2040 , it is predicted that the productivity of the river will increase by a maximum value of $9 \%$ (BMRC98) with a minimum increase of 5\% (GFDL90). By the year 2050, it is predicted that productivity will increase by a maximum value of $7 \%$ (BMRC98) with a minimum decrease of $-1 \%$ (CCCM199). By the year 2060, it is anticipated that productivity will rise by a maximum value of $9 \%$ (BMRC98) with a minimum increase of 7\% (CCCM199). Through the year 2070, it is predicted that productivity will surge by a maximum value of $10 \%$ (BMRC98) with a minimum increase of 8\% (CCCM199). By the year 2075, the productivity will increase by a maximum value of $11 \%$ (BMRC98) with a minimum increase of 8\% (CCCM199). Through the year 2080, it is predicted that productivity will increase by a maximum value of $11 \%$ (BMRC98) with a minimum increase of 8\% (CCCM199). By the year 2090, it is predicted that productivity will increase by a maximum value of $12 \%$ (BMRC98) with a minimum increase of $9 \%$ (CCCM199). Finally, by the year 2100, it is predicted that productivity will increase by a maximum value of $13 \%$ (BMRC98) with a minimum increase of 10\% (CCCM199). 


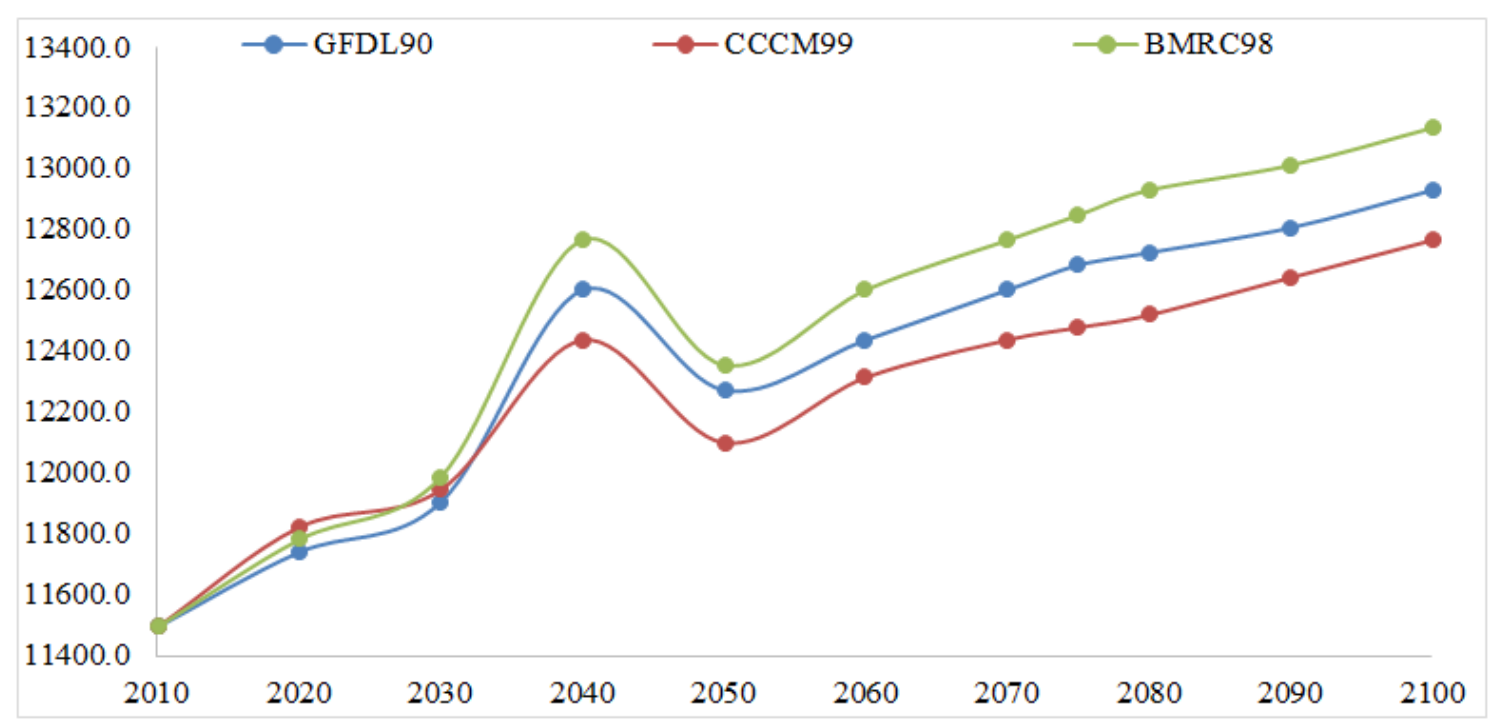

Figure 4. Annual Productivity of River Gambia in support of fisheries resources (MT/Km) against Scenarios (Years)

\subsection{Assessment of the Effects of Temperature Changes on Shrimp Yield}

Figure 5 shows the stabilized commercial shrimp yield $(\mathrm{Kg} / \mathrm{Ha})$ of the River Gambia as estimated with the mean air temperature under varied GCMs temperature scenarios. The Stabilized Commercial Shrimp Yield (SCSY) of the River Gambia based on a temperature of $28.0^{\circ} \mathrm{C}$ is (from years 1981 - 2010) $87.8 \mathrm{Kg} / \mathrm{Ha}$.

In synopsis, the results of the analysis revealed that the stabilized commercial shrimp yield would increase by a value of $34 \%$ in 2060 with a steady increase to $46 \%$ by the year 2100 under the varied GCM scenarios. This result is supported by Turner [54] revealing a positive trend in the current and future projections of Penaeid shrimp yield over varied mean air temperature. Wyban et al [55] study revealed a positive impact of temperature on the growth and feeding rate of Penaeus vannamei species of white shrimps. When the temperature optima are reached (around $35^{\circ} \mathrm{C}$ ) it is the matured shrimps that continued to show a positive trend while that of the juveniles gradually dip in trend with excess temperature surge [55]. There is the need to protect more mangrove ecosystems to provide the temperature regulatory services for maximum growth and survival of juvenile shrimps. This supports the results of this study. Regier et al [29] study revealed a positive relationship between temperature and stabilized commercial shrimp yield further supporting the results of this study.

In elucidation, by the year 2020, it is predicted that SCSY of the River Gambia will increase by a maximum value of 10\%(BMRC98) with a minimum increase of $6 \%(C C C M 199)$. By the year 2030, it is anticipated that SCSY of the River Gambia will increase by a maximum value of $17 \%($ BMRC98) with a minimum increase of $9 \%$ (CCCM199). By the year 2040, it is predicted that SCSY of the River Gambia will increase by a maximum value of
34\%(BMRC98) with a minimum increase of $15 \%$ (CCCM199). By the year 2050, it is foreseen that SCSY of the River Gambia will increase by a maximum value of 28\%(BMRC98) with a minimum increase of 21\%(CCCM199). By the year 2060, it is anticipated that SCSY of the River Gambia will increase by a maximum value of 34\%(BMRC98) with a minimum increase of 26\%(CCCM199). By the year 2070, it is predicted that SCSY of the River Gambia will increase by a maximum value of 38\%(BMRC98) with a minimum increase of $30 \%(C C C M 199)$. By the year 2075, it is predicted that SCSY of the River Gambia will increase by a maximum value of $40 \%$ (BMRC98) with a minimum increase of $34 \%(C C C M 199)$. By the year 2080, it is predicted that SCSY of the River Gambia will increase by a maximum value of 35\% (BMRC98) with a minimum increase of $30 \%$ (CCCM199). By the year 2090, it is predicted that SCSY of the River Gambia will increase by a maximum value of 44\%(BMRC98) with a minimum increase of $36 \%$ (CCCM199). Finally, by the year 2100, it is predicted that SCSY of the River Gambia will rise by a maximum value of $46 \%$ (BMRC98) with a minimum increase of $37 \%$ (CCCM199).

The observed positive trend in stabilized commercial shrimp yield under varied temperature scenarios may be because of the inclination and flexibility of shrimps to warm waters; which is characteristic of River Gambia estuary ranges. Shrimps are likewise fit for living amid the chilly season in cool waters not dipping below $18^{0} \mathrm{C}[12$, 56]. Other reasons for the increase in shrimp yield owes to there being no recorded industrial fishing activity on the River Gambia ensuing an ideal environment for shrimp farming. There is no significant pollution from up-river; implying shrimps can be farmed in The Gambia without antibiotics. 


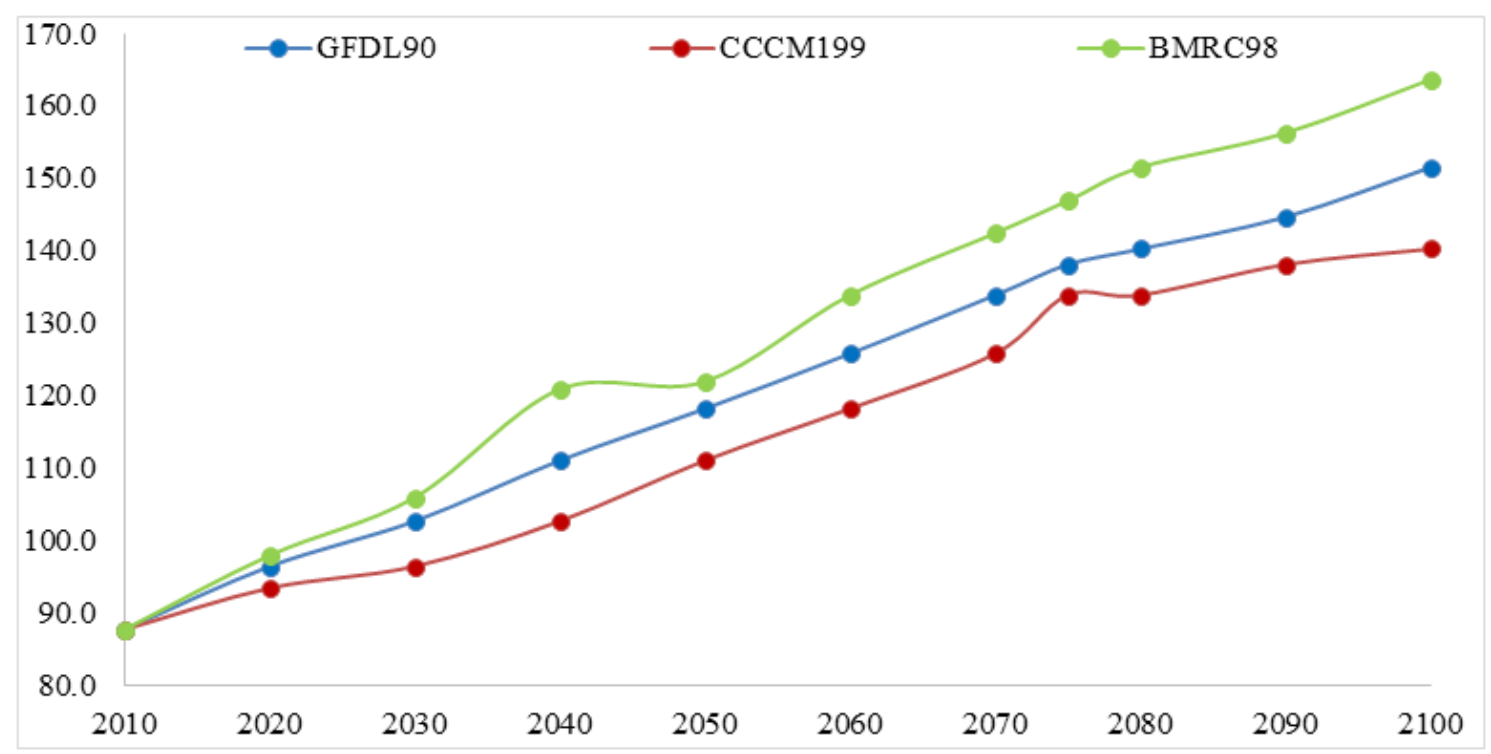

Figure 5. Stabilized Commercial Shrimp Yield (Kg/Ha) against Scenarios (Years)

\section{Conclusions and Recommendations}

The results of the trend analysis revealed that annual industrial fishery catches in The Gambia showed a decreasing trend of 534 MT per annum over the period 1968-2014. This observed negative trend is predicted to persist with a noteworthy decrease from 4,770 MT in 2014 to 66.7 MT by the year 2025 .

The artisanal fisheries sector of The Gambia revealed a positive trend of 1,611 MT of fisheries resources from 1986-2016. It is predicted that the observed increase in artisanal fishery catches will persist to the year 2025. This corresponds to an increase of 21\% from by the year 2025 .

The analysis of the effects of temperature changes on shrimp yield in The Gambia showed a potential increase of $46 \%$ by the year 2100 .

The analysis of the effects of temperature on the productivity of the fisheries resources of the River Gambia revealed a potential increase of $13 \%$ by the year 2100 . This result reveals that The Gambia maritime space, and the River Gambia ranges, will continue to be productive in the support of shrimp and other artisanal fisheries resources under the anticipated climate change impacts over the coastal zone in the short-long term.

To help reverse the trend in the industrial fishery catches, it is imperative for the Government of The Gambia to set-up and substantively build the capacity of more patrol vessels to regulate Illegal, Unreported and Unregulated fishing in the coastal zone of the Gambia.

It is imperative that the process of obtaining and renewing industrial fishing licenses be facilitated. The study suggests the establishment of a deep-marine fishing port to increase the number of industrial fisheries landings in The Gambia.
Although the artisanal fisheries sector revealed a positive trend, there should continuous monitoring and enforcement of laws and regulations against unsustainable fishing operations like blast fishing or use of dynamite in fishing. The study suggests there should be more programs and partnerships with financial institutions to give artisanal fisherfolk more access to operational funds. More Gambian youth should be trained in repair and maintenance of mechanized fishing gears. It is also imperative that the number of premixed fuel stations within the country is increased and its pricing regulated for easy access and purchase for artisanal fishing operations.

It is suggested that there should be more afforestation programs to increase the population of mangroves in local wetlands and the introduction of more adaptive species of mangroves that can better withstand areas with high salinity owing to sea-level rise impacts. With this in place, fisheries nesting grounds will be increased to help produce and care for juvenile fisheries resources before they migrate to the deeper waters at maturity. This will further increase the productivity of the River Gambia in support of fisheries resources.

\section{Acknowledgements}

I am grateful to the German Government, West African Science Service Center on Climate Change and Adapted Land Use (WASCAL) and the German Federal Ministry of Education and Research (BMBF) for their financial contribution towards this research. I am very grateful to Mrs. Theresa Aniagyei-Bonsu for all her enormous support and motivation. I also thank all other anonymous contributors to this work. 


\section{Appendix A}

General Circulation Model (GCMs) Data

\begin{tabular}{|c|c|c|c|c|c|c|c|c|c|c|c|c|c|}
\hline \multicolumn{14}{|c|}{ Projected Change in Temperature (Delta T) - CCC199 } \\
\hline & JAN & FEB & MAR & APR & MAY & JUN & JUL & AUG & SEPT & OCT & NOV & DEC & ANNUAL \\
\hline 2020 & 0.9 & 0.9 & 0.8 & 0.7 & 0.7 & 0.7 & 0.6 & 0.7 & 0.8 & 0.8 & 0.8 & 0.9 & 0.8 \\
\hline 2030 & 1.2 & 1.3 & 1.2 & 1.0 & 1.0 & 1.0 & 0.9 & 1.0 & 1.1 & 1.1 & 1.1 & 1.2 & 1.1 \\
\hline 2040 & 1.5 & 1.6 & 1.5 & 1.3 & 1.3 & 1.3 & 1.1 & 1.2 & 1.4 & 1.4 & 1.4 & 1.5 & 1.4 \\
\hline 2050 & 1.8 & 2.0 & 1.8 & 1.6 & 1.6 & 1.6 & 1.4 & 1.5 & 1.6 & 1.7 & 1.7 & 1.9 & 1.7 \\
\hline 2060 & 2.2 & 2.3 & 2.1 & 1.9 & 1.8 & 1.9 & 1.6 & 1.7 & 1.9 & 2.0 & 2.0 & 2.2 & 1.9 \\
\hline 2070 & 2.5 & 2.7 & 2.4 & 2.1 & 2.1 & 2.1 & 1.8 & 2.0 & 2.2 & 2.2 & 2.4 & 2.5 & 2.2 \\
\hline 2075 & 2.7 & 2.8 & 2.5 & 2.3 & 2.2 & 2.3 & 2.0 & 2.1 & 2.3 & 2.4 & 2.5 & 2.7 & 2.4 \\
\hline 2080 & 2.8 & 3.0 & 2.7 & 2.4 & 2.4 & 2.4 & 2.1 & 2.3 & 2.5 & 2.5 & 2.6 & 2.8 & 2.5 \\
\hline 2090 & 3.1 & 3.3 & 3.0 & 2.7 & 2.7 & 2.6 & 2.3 & 2.5 & 2.8 & 2.8 & 2.9 & 3.2 & 2.8 \\
\hline 2100 & 3.4 & 3.7 & 3.3 & 2.9 & 2.9 & 2.9 & 2.5 & 2.7 & 3.0 & 3.1 & 3.2 & 3.5 & 3.1 \\
\hline \multicolumn{14}{|c|}{ Baseline and CCC199 Projections of Mean Temperature of The Gambia } \\
\hline & JAN & FEB & MAR & APR & MAY & JUN & JUL & AUG & SEPT & OCT & NOV & DEC & ANNUAL \\
\hline $1981-2010$ & 24.7 & 26.9 & 28.8 & 29.7 & 30.4 & 29.8 & 28.3 & 27.7 & 27.7 & 28.5 & 27.2 & 25.2 & 27.9 \\
\hline 2020 & 25.6 & 27.8 & 29.6 & 30.4 & 31.4 & 30.5 & 28.9 & 28.4 & 28.5 & 29.3 & 28.0 & 26.1 & 28.7 \\
\hline 2030 & 25.9 & 28.2 & 30.0 & 30.7 & 31.4 & 30.8 & 29.2 & 28.7 & 28.8 & 29.6 & 28.3 & 26.4 & 29.0 \\
\hline 2040 & 26.2 & 28.5 & 30.3 & 31.0 & 31.7 & 31.1 & 29.4 & 28.9 & 29.1 & 29.9 & 28.6 & 26.7 & 29.3 \\
\hline 2050 & 26.5 & 28.9 & 30.6 & 31.3 & 32.0 & 31.4 & 29.7 & 29.2 & 29.3 & 30.2 & 28.9 & 27.1 & 29.6 \\
\hline 2060 & 26.9 & 29.2 & 30.9 & 31.6 & 32.2 & 31.7 & 29.9 & 29.4 & 29.6 & 30.5 & 29.2 & 27.4 & 29.8 \\
\hline 2070 & 27.2 & 29.6 & 31.2 & 31.8 & 32.5 & 31.9 & 30.1 & 29.7 & 29.9 & 30.7 & 29.6 & 27.7 & 30.1 \\
\hline 2075 & 27.4 & 29.7 & 31.3 & 32.0 & 32.6 & 32.1 & 30.3 & 29.8 & 30.0 & 30.9 & 29.7 & 27.9 & 30.3 \\
\hline 2080 & 27.5 & 29.9 & 31.5 & 32.1 & 32.8 & 32.2 & 30.4 & 30.0 & 30.2 & 31.0 & 29.8 & 28.0 & 30.4 \\
\hline 2090 & 27.8 & 30.2 & 31.8 & 32.4 & 33.1 & 32.4 & 30.6 & 30.2 & 30.5 & 31.3 & 30.1 & 28.4 & 30.7 \\
\hline 2100 & 28.1 & 30.6 & 32.1 & 32.6 & 33.3 & 32.7 & 30.8 & 30.4 & 30.7 & 31.6 & 30.4 & 28.7 & 31.0 \\
\hline \multicolumn{14}{|c|}{ Projected Change in Temperature (Delta T) - BMRC98 Model } \\
\hline & JAN & FEB & MAR & APR & MAY & JUN & JUL & AUG & SEPT & OCT & NOV & DEC & ANNUAL \\
\hline 2020 & 0.7 & 0.7 & 0.7 & 1.1 & 0.6 & 0.6 & 0.8 & 0.8 & 0.8 & 0.6 & 0.7 & 0.7 & 0.7 \\
\hline 2030 & 1.2 & 1.1 & 1.2 & 1.1 & 1.0 & 1.0 & 1.2 & 1.4 & 1.2 & 1.2 & 1.1 & 1.2 & 1.1 \\
\hline 2040 & 1.7 & 1.6 & 1.7 & 1.7 & 1.5 & 1.5 & 1.8 & 2.0 & 1.8 & 1.7 & 1.7 & 1.7 & 1.7 \\
\hline 2050 & 2.1 & 2.0 & 2.1 & 2.1 & 1.9 & 1.9 & 2.2 & 2.6 & 2.3 & 2.1 & 2.1 & 2.2 & 2.1 \\
\hline 2060 & 2.7 & 2.6 & 2.6 & 2.6 & 2.3 & 2.3 & 2.8 & 3.1 & 2.9 & 2.6 & 2.6 & 2.7 & 2.6 \\
\hline 2070 & 3.1 & 3.0 & 3.1 & 3.0 & 2.8 & 2.7 & 3.2 & 3.7 & 3.3 & 3.1 & 3.0 & 3.2 & 3.1 \\
\hline 2075 & 3.3 & 3.1 & 3.3 & 3.2 & 2.9 & 2.9 & 3.5 & 3.9 & 3.6 & 3.3 & 3.2 & 3.4 & 3.3 \\
\hline 2080 & 3.5 & 3.3 & 3.4 & 3.3 & 3.0 & 3.0 & 3.6 & 4.1 & 3.7 & 3.4 & 3.4 & 3.5 & 3.4 \\
\hline 2090 & 3.7 & 3.6 & 3.7 & 3.6 & 3.3 & 3.2 & 3.9 & 4.5 & 4.1 & 3.7 & 3.7 & 3.8 & 3.7 \\
\hline 2100 & 4.0 & 3.8 & 3.9 & 3.9 & 3.5 & 3.5 & 4.1 & 4.7 & 4.3 & 3.9 & 3.9 & 4.0 & 3.9 \\
\hline \multicolumn{14}{|c|}{ Baseline and BMRC98 Model Projections of Mean Temperature of The Gambia } \\
\hline & JAN & FEB & MAR & APR & MAY & JUN & JUL & AUG & SEPT & OCT & NOV & DEC & ANNUAL \\
\hline $1981-2010$ & 24.7 & 26.9 & 28.8 & 29.7 & 30.4 & 29.8 & 28.3 & 27.7 & 27.7 & 28.5 & 27.2 & 25.2 & 27.9 \\
\hline 2020 & 25.4 & 27.6 & 30.7 & 30.8 & 31.0 & 30.4 & 29.1 & 28.5 & 28.5 & 29.1 & 27.9 & 25.9 & 28.6 \\
\hline 2030 & 25.9 & 28.0 & 30.0 & 30.8 & 31.4 & 30.8 & 29.5 & 29.1 & 28.9 & 29.7 & 28.3 & 26.4 & 29.0 \\
\hline 2040 & 26.4 & 28.5 & 30.5 & 31.4 & 31.9 & 31.3 & 30.1 & 29.7 & 29.5 & 30.2 & 28.9 & 26.9 & 29.6 \\
\hline 2050 & 26.8 & 28.9 & 30.9 & 31.8 & 32.3 & 31.7 & 30.5 & 30.3 & 30.0 & 30.6 & 29.3 & 27.4 & 30.0 \\
\hline
\end{tabular}




\begin{tabular}{|c|c|c|c|c|c|c|c|c|c|c|c|c|c|}
\hline 2060 & 27.4 & 29.5 & 31.4 & 32.3 & 32.7 & 32.1 & 31.1 & 30.8 & 30.6 & 31.1 & 29.8 & 27.9 & 30.5 \\
\hline 2070 & 27.8 & 30.0 & 31.9 & 32.7 & 33.2 & 32.5 & 31.5 & 31.4 & 31.0 & 31.6 & 30.2 & 28.4 & 31.0 \\
\hline 2075 & 28.0 & 30.2 & 32.1 & 32.9 & 33.3 & 32.7 & 31.8 & 31.6 & 31.3 & 31.8 & 30.4 & 28.6 & 31.2 \\
\hline 2080 & 28.2 & 30.3 & 32.2 & 33.0 & 33.4 & 32.8 & 31.9 & 31.8 & 31.4 & 31.9 & 30.6 & 28.7 & 31.3 \\
\hline 2090 & 28.4 & 30.5 & 32.5 & 33.3 & 33.7 & 33.0 & 32.2 & 32.2 & 31.8 & 32.2 & 30.9 & 29.0 & 31.6 \\
\hline 2100 & 28.7 & 30.7 & 32.7 & 33.6 & 33.9 & 33.3 & 32.4 & 32.4 & 32.0 & 32.4 & 31.1 & 29.2 & 31.8 \\
\hline \multicolumn{14}{|c|}{ Projected Change in Temperature (Delta T) - GFDL90 Model } \\
\hline & JAN & FEB & MAR & APR & MAY & JUN & JUL & AUG & SEPT & OCT & NOV & DEC & ANNUAL \\
\hline 2020 & 0.7 & 0.7 & 0.7 & 0.6 & 0.6 & 0.6 & 0.5 & 0.5 & 0.6 & 0.6 & 0.6 & 0.7 & 0.6 \\
\hline 2030 & 1.1 & 1.2 & 1.1 & 0.9 & 0.9 & 1.0 & 0.8 & 0.9 & 0.9 & 1.0 & 1.0 & 1.1 & 1.0 \\
\hline 2040 & 1.6 & 1.7 & 1.6 & 1.4 & 1.4 & 1.4 & 1.2 & 1.3 & 1.4 & 1.5 & 1.5 & 1.7 & 1.4 \\
\hline 2050 & 2.1 & 2.2 & 2.0 & 1.8 & 1.8 & 1.7 & 1.6 & 1.6 & 1.7 & 1.9 & 1.9 & 2.1 & 1.8 \\
\hline 2060 & 2.6 & 2.7 & 2.4 & 2.2 & 2.1 & 2.1 & 1.9 & 2.0 & 2.2 & 2.3 & 2.4 & 2.6 & 2.3 \\
\hline 2070 & 3.0 & 3.2 & 2.9 & 2.5 & 2.5 & 2.5 & 2.3 & 2.3 & 2.5 & 2.7 & 2.7 & 3.1 & 2.7 \\
\hline 2075 & 3.2 & 3.4 & 3.0 & 2.7 & 2.7 & 2.7 & 2.4 & 2.5 & 2.6 & 2.9 & 2.9 & 3.3 & 2.8 \\
\hline 2080 & 3.4 & 3.6 & 3.2 & 2.9 & 2.8 & 2.8 & 2.5 & 2.6 & 2.8 & 3.1 & 3.1 & 3.4 & 3.0 \\
\hline 2090 & 3.6 & 3.9 & 3.4 & 3.1 & 3.0 & 3.0 & 2.7 & 2.8 & 3.0 & 3.3 & 3.3 & 3.7 & 3.2 \\
\hline 2100 & 3.9 & 4.1 & 4.0 & 3.2 & 3.2 & 3.2 & 2.9 & 2.9 & 3.2 & 3.5 & 3.6 & 3.9 & 3.4 \\
\hline \multicolumn{14}{|c|}{ Baseline and GFDL90 Model Projections of Mean Temperature of The Gambia } \\
\hline & JAN & FEB & MAR & APR & MAY & JUN & JUL & AUG & SEPT & OCT & NOV & DEC & ANNUAL \\
\hline $1981-2010$ & 24.7 & 26.9 & 28.8 & 29.7 & 30.4 & 29.8 & 28.3 & 27.7 & 27.7 & 28.5 & 27.2 & 25.2 & 27.9 \\
\hline 2020 & 25.4 & 27.6 & 29.5 & 30.3 & 31.0 & 30.4 & 28.8 & 28.2 & 28.3 & 29.1 & 27.8 & 25.9 & 28.5 \\
\hline 2030 & 25.8 & 28.1 & 29.9 & 30.6 & 31.3 & 30.8 & 29.1 & 28.6 & 28.6 & 29.5 & 28.2 & 26.3 & 28.9 \\
\hline 2040 & 26.3 & 28.6 & 30.4 & 31.1 & 31.8 & 31.2 & 29.5 & 29.0 & 29.1 & 30.0 & 28.7 & 26.9 & 29.3 \\
\hline 2050 & 26.8 & 29.1 & 30.8 & 31.5 & 32.2 & 31.5 & 29.9 & 29.3 & 29.4 & 30.4 & 29.1 & 27.3 & 29.7 \\
\hline 2060 & 27.3 & 29.6 & 31.2 & 31.9 & 32.5 & 31.9 & 30.2 & 29.7 & 29.9 & 30.8 & 29.6 & 27.8 & 30.2 \\
\hline 2070 & 27.7 & 30.1 & 31.7 & 32.2 & 32.9 & 32.3 & 30.6 & 30.0 & 30.2 & 31.2 & 29.9 & 28.3 & 30.6 \\
\hline 2075 & 27.9 & 30.3 & 31.8 & 32.4 & 33.1 & 32.5 & 30.7 & 30.2 & 30.3 & 31.4 & 30.1 & 28.5 & 30.7 \\
\hline 2080 & 28.1 & 30.5 & 32.0 & 32.6 & 33.2 & 32.6 & 30.8 & 30.3 & 30.5 & 31.6 & 30.3 & 28.6 & 30.9 \\
\hline 2090 & 28.3 & 30.8 & 32.2 & 32.8 & 33.4 & 32.8 & 31.0 & 30.5 & 30.7 & 31.8 & 30.5 & 28.9 & 31.1 \\
\hline 2100 & 28.6 & 31.0 & 32.8 & 32.9 & 33.6 & 33.0 & 31.2 & 30.6 & 30.9 & 32.0 & 30.8 & 29.1 & 31.3 \\
\hline
\end{tabular}

\section{REFERENCES}

[1] FAO (2017). FAO Global Capture Production database updated to 2015 - Summary information. Food and Agricultural Organization, 1-7.

[2] FAO (2014). The Value of African Fisheries. Food and Agriculture Organization Fisheries and Aquaculture Circular, 1093, 1-9.

[3] Nadje S D (2012). Regional Assessment of Fisheries Issues, Challenges and Opportunities in West African Region: Towards the Formulation of the Policy Framework and Reform Strategy for Fisheries and Aquaculture in Africa. African Union- Inter-African Bureau for Animal Resources (AU-IBAR), (December), 1-40.

[4] UNECA (2012). Harnessing Agricultural Potential for

Growth and Development in West Africa. United Nations Economic Commission for Africa, 1, 1-12.

[5] Dahou K, Déme M, Ndiaye P G, Diouf P S, Coulibaly D, Sané K, Thiam D (2007). Trade liberalisation and sustainable management of fishery's sector in West Africa. Case study of Senegal. Enda Tiers-Monde.

[6] Mohammed E Y, Uraguchi Z B (2013). Impacts of Climate Change on Fisheries: Implications for food security in sub-Saharan Africa. Book: Global Food Security: Emerging Issues and Economic Implications, 113-136.

[7] Bah M, Tobey J, Drammeh O (2010). Artisanal Shrimp (Prawn) Fishery, 1-21.

[8] Mendy A (2003). A Trophic Model of the Gambian continental Shelf system for 1982 and 1995 using Ecopath and Ecosim. Trophic Models of Northwest Africa Marine Ecosystems, 1-32.

[9] Allison E H, Adger W N, Badjeck M-C, Brown K, Conway D, Dulvy N K, ... Reynolds J D (2005). Effects of climate 
change on the sustainability of capture and enhancement fisheries important to the poor: analysis of the vulnerability and adaptability of fisherfolk living in poverty. Final Technical Report, 154-164.

[10] Belhabib D, Pauly D (2015). Reconstructing fisheries catches for Cameroon between 1950 and 2010. Fisheries Centre Working Paper, 4, 1-9.

[11] Lee V, Tobey J, Castro K, Crawford B, Ibrahima M, Drammeh O, Vaidyanathan T (2009). Marine Biodiversity Assets and Threats Assessment: Gambia-Senegal Sustainable Fisheries Project. Rhode Island, NY: Coastal Resources Center, University of Rhode Island, 1-50.

[12] National Climate Committee (2013). Second National Communication of the Republic of the Gambia to the United Nations Framework Convention on Climate Change. UNFCCC, 1-163.

[13] WTO (2017). Challenges and Opportunities for Small Scale fishers in Fish Trade. Retrieved from http://www.google.com/logos/doodles/2017/new-years-eve2017-5093547849023488-2xa.gif

[14] Groeneveld (2015). Capture Fisheries. http://www.fao.org/fishery/countryprofiles/search/en

[15] Tvedten I, Hersoug B (1992). Fishing for development: Small-scale fisheries in Africa. Nordic Africa Institute.

[16] OECD (2006). Exploring Economic Opportunities in sustainable shrimp farming in West Africa: focus on south-south cooperation, 1-12.

[17] Lowther A (2006). Highlights from the FAO database on Aquaculture Statistics. FAO Aquacult Newsletter, 35, 3233.

[18] Van Hoof L, Kraan M (2017). Mission report Tanzania: scoping mission marine fisheries Tanzania. Wageningen Marine Research.

[19] FAO (2007b). National Fishery Sector Overview: The Republic of Kenya. Food and Agricultural Organization, 15.

[20] IPCC (2014). Climate Change 2014-Impacts, Adaptation and Vulnerability: Regional Aspects. Cambridge University Press.

[21] Drinkwater K F, Beaugrand G, Kaeriyama M, Kim S, Ottersen G, Perry R I, ... Takasuka A (2010). On the processes linking climate to ecosystem changes. Journal of Marine Systems, 79(3), 374-388.

[22] Brander K M (2007). Global fish production and climate change. Proceedings of the National Academy of Sciences, 104(50), 19709-19714.

[23] Mackay A (2008). Climate change 2007: impacts, adaptation and vulnerability. Contribution of Working Group II to the fourth assessment report of the Intergovernmental Panel on Climate Change. Journal of Environmental Quality, 37(6), 2407-2407.

[24] FAO (2009). Expert meeting on impacts of destructive fishing practices, unsustainable fishing, and illegal, unreported and unregulated (IUU) fishing on marine biodiversity and habitats. Rome: FAO/UNEP.
[25] Cinner J, McClanahan T R, Wamukota A, Darling E, Humphries A, Hicks C, ...Graham N (2013). Social-ecological vulnerability of coral reef fisheries to climatic shocks. FAO Fisheries and Aquaculture Circular (FAO) Eng. No. 1082, 1-15.

[26] Welcomme R L (1979). Fisheries ecology of floodplain rivers [tropics]. UK: Longman.

[27] MOA (2015). The Republic of the Gambia Agriculture and Natural Resources (ANR) Policy (2009- 2015). Department of Agriculture. The Republic of the Gambia, July(1), 1-98.

[28] Jallow B P, Barrow M K A (1997). Vulnerability and adaptation assessment for the coastal resources sector, 35-49. GOTG-USCP.

[29] Regier H A, Holmes J A, Pauly D. (1990). Influence of temperature changes on aquatic ecosystems: an interpretation of empirical data. Transactions of the American Fisheries Society, 119(2), 374-389.

[30] Duplisea D E, Blanchard F. (2005). Relating species and community dynamics in an heavily exploited marine fish community. Ecosystems, 8(8), 899-890.

[31] Sundar (2016). Research Methods to Assess the Impact of Climate Change on Fisheries. EPRA Journal of Economic and Business Review, 509(September), 1-6.

[32] Groeneveld J C, Fennesy S T, Everett B I, Robey J (2014) Rapid Assessment of the State of Commercial Fisheries and Main Species Exploited in Tanzania. Specialist Report. Oceanographic Research Institute, 1-24.

[33] Jiddawi N S, Öhman M C (2002). Marine fisheries in Tanzania. Ambio: A Journal of the Human Environment, 31(7), 518-527.

[34] FAO (2005). National Fishery Sector Overview: The Republic of Seychelles. Food and Agricultural Organization, $1-5$.

[35] FAO (2006). National Fishery Sector Overview: The Republic of Mauritius. Food and Agricultural Organization, $1-5$

[36] FAO (2007a). National Fishery Sector Overview, Fishery Country Profile - The Gambia. Food and Agricultural Organization, 1-5.

[37] FAO (2008). National Fishery Sector Overview: The Republic of Madagascar. FAO, Rome. Food and Agricultural Organization, 1-6.

[38] Le Manacha F, Goughb C, Humberb F, Harperc S, Zellerc D (2011). Reconstruction of total marine fisheries catches for Madagascar. Fisheries Centre Research Reports, 19(4), 21.

[39] Simpkins M (2012). Addressing bycatch in artisanal gill nets, 23-50.

[40] Belhabib D, Greer K, Pauly D (2017). Trends in Industrial and Artisanal Catch Per Effort in West African Fisheries. Conservation Letters, 1(March), 1-10.

[41] Alder J, Sumaila U R (2004). Western Africa: a fish basket of Europe past and present. The Journal of Environment \& Development, 13(2), 156-178.

[42] Perez J A A, Wahrlich R, Pezzuto P R, Schwingel P R, Lopes F R A, Rodrigues-Ribeiro M (2003). Deep-sea 
Fishery off Southern Brail: Recent Trends of the Brazilian Fishing Industry. Journal of Northwest Atlantic Fishery Science, 31, 1.

[43] Tobey J, Castro K, Lee V, Drammeh O, Ibrahima M D, Crawford B, Vaidyanathan T (2009). An Overview of Marine Fisheries in the Gambia and Preliminary Governance Baseline. Coastal Resources Center, University of Rhode Island, 1-26.

[44] GoG (2010). Fisheries Policy of the Gambia- Draft. Department of State for Fisheries and Water Resources. The Government of the Gambia, 1-46.

[45] Agnew D J, Pearce J, Pramod G, Peatman T, Watson R, Beddington J R, Pitcher T J (2009). Estimating the worldwide extent of illegal fishing. Plos One, 4(2), e4570.

[46] Tobey J, Normanyo A K, Osei P, Beran K, Crawford, B (2016). Subsidies in Ghana's Marine Artisanal Fisheries Sector. USAID/Ghana Sustainable Fisheries Management Project (SFMP). Coastal Resources Center, Graduate School of Oceanography, University of Rhode Island., 1-50.

[47] Onemolease E A, Oriakhi H O (2011). Prospects and constraints of artisanal fishing in selected communities in Delta State, Nigeria. Advances in Applied Science Research, 2(6), 55-61.

[48] Akanni K A (2008). Catch levels and capital investment of artisanal fishermen in Lagos State, Nigeria. Turkish Journal of Fisheries and Aquatic Sciences, 8(2).
[49] Diegues A C, Vasconcellos M, Kalikoski C D (2006). Artisanal fisheries in Brazil, 1-12.

[50] Randall R G, Minns C K, Kelso J R M (1995). Fish production in freshwaters: are rivers more productive than lakes? Canadian Journal of Fisheries and Aquatic Sciences, 52(3), 631-643.

[51] Acreman M C (2010). Catchment Management Case StudySenegal River. Handbook of Catchment Management, 1377.

[52] Houde E D, Rutherford E S (1993). Recent trends in estuarine fisheries: predictions of fish production and yield. Estuaries and Coasts, 16(2), 161-176.

[53] Gehrke P C, Brown P, Schiller C B, Moffatt D B, Bruce A M (1995). River regulation and fish communities in the Murray-Darling river system, Australia. River Research and Applications, 11(3-4), 363-375.

[54] Turner R E (1977). Intertidal vegetation and commercial yields of penaeid shrimp. Transactions of the American Fisheries Society, 106(5), 411-416.

[55] Wyban J, Walsh W A, Godin D M (1995). Temperature effects on growth, feeding rate and feed conversion of the Pacific white shrimp (Penaeus vannamei). Aquaculture, 138(1), 267-279.

[56] NAPA (2007). The Gambia National Adaptation Programme of Action (NAPA) on Climate Change. Government of the Gambia, Banjul. 